\begin{tabular}{llll}
\hline Estudios de Economía Aplicada & Vol. 30-2 $2012 \quad$ PÁgs. 733-746 \\
\hline
\end{tabular}

\title{
Información útil para el análisis de la Economía del Deporte
}

\section{PABLO CASTELLANOS GARCÍA}

Departamento de Economía Aplicada I, UNIVERSIDAD DE A CORUÑA, ESPAÑA. Email: pcg@udc.es

\section{JOSÉ MANUEL SÁNCHEZ SANTOS}

Departamento de Economía Aplicada I, UNIVERSIDAD DE A CORUÑA, ESPAÑA. Email: santos67@udc.es

\section{Referencias bibliográficas MANUALES}

BLAIR, D. (2011), Sports Economics, Cambridge: Cambridge University Press.

DOWNWARD, P. y DAWSON, A. (2000), The Economics of Professional Team Sports, London: Routledge.

DOWNWARD, P. DAWSON, A. y DEJONGHE, T. (2009), Sports economics: Theory, evidence and policy, London: Elsevier.

ESCHENFELDER, M.J. y LI, M. (2006); Economics of Sport, Morgantown: Fitness Information Technology; Second Edition.

FORT, R. (2010), Sports Economics, Upper Saddle River: Prentice Hall; Third edition.

SANDY, R.; SLOANE, P. y ROSENTRAUB (2004), The Economics of Sport: An International Perspective, New York: Palgrave Macmillan.

VON ALLMEN, P. y LEEDS, M.A. (2008), The Economics of Sport, London: Addison Wesley. Fourth Edition.

\section{Referencias bibliográficas LIBROS}

ANDREFF, W.; BOURG, J.F.; HALBA, B. Y NYS, J.F. (1995), Les enjeux économiques du sport en Europe: Financement et impact économique, Conseil de l'Europe: Editions Dalloz.

ANDREFF. W. (2011) (Ed.), Recent Developments in the Economics of Sports, Cheltenham: Edward Elgar.

ANDREFF, W. (2011), Contemporary Issues in Sports Economics: Participation and Professional Team Sports, Cheltenham: Edward Elgar.

ANDREFF, W. y SZYMANSKI, S. (Eds.), (2006), Handbook on the Economics of Sport, Cheltenham: Edward Elgar.

BARROS, C. P.; IBRAHIMO, M. y SZYMANSKI, S. (2002), Transatlantic Sport: The Comparative Economics of North American and European Sports, Cheltenham: Edward Elgar. 
BERRI, D.J. y SCHMIDT, M.B.(2010), Stumbling On Wins: Two Economist Expose the Pitfalls on the Road to Victory in Professional Sports, Upper Saddle River: FT Press.

BERRI, D.J.; SCHMIDT, M.B. y BROOK, S.L. (2006), The Wages of Wins: Taking Measure of the Many Myths in Modern Sport, Stanford: Stanford University Press.

BERRY, R.C. ; GOULD, W.B. Y STAODOHAR, P.D. (1986), Labor relations in professional sports, Dover, Mass.: Auburn House Publishing Company.

BOURG, J.F. y GOUGUET, J.J. (1998), Analyse économique du sport, Paris: Presses Universitaires de France.

BOURG, J.F. y GOUGUET, J.J. (2010), The Political Economy of Professional Sport, Cheltenham: Edward Elgar.

CONN, D. (1997), The Football Business, Edinburgh and London: Mainstream Publishing.

DEMMERT, H.G. (1973), The Economics of Professional Team Sports, Lexington, Mass.: Lexington Books.

DOBSON S. y GODDARD, J. (2011), The Economics of Football, New York: Cambridge University Press

EUCHNER, C.C. (1994), Playing the Field. Why Sports Teams Move and Cities Fight to Keep Them, Baltimore and London: The Johns Hopkins University Press.

FIZEL, J. (Ed.) (2006), Handbook of Sports Economics Research, London: M.A. Sharpe.

FIZEL, J. y FORT, R. (2004), Economics of College Sports, Westport: Praeger Publishers.

FIZEL, J.; GUSTAFSON, E. y HADLEY, L. (Eds.) (1996), Baseball Economics: Current Research, Westport: Praeger Publishers.

FIZEL, J.; GUSTAFSON, E. y HADLEY, L. (Eds.) (1999), Sport Economics: Current Research, Westport: Praeger Publishers.

FLEISHER, A.A.; GOFF, B.L. y TOLLISON, R.D. (1992), The National Collegiate Athletic Association. A Study in Cartel Behavior, Chicago and London: The University of Chicago Press.

FORT, R. y FIZEL, J. (Eds.) (2004), International Sports Economics Comparisons, London: Praeger Publishers.

GERRARD, B. (2006), The Economics of Association Football, Cheltenham: Edward Elgar. 2 vol.

GOFF, B.L. y TOLLISON, R.D. (Eds.) (1990), Sportometrics, Texas A\&M University Press

GRATTON, C. y HENRY, I. (2002), Sport in the City: the role of sport in economic and social regeneration, London: Routledge.

GRATTON, C. y SOLBERG, H. (2007), The Economics of Sport Broadcasting, London: Routledge.

GRATTON, C. y TAYLOR, P. (2000), Economics of Sport and Recreation, New York: Spon Press.

GRATTON, C., LIU, D. RAMCHANDANI, G. y WILSON, D. (2012), The Global Economics of Sport, London: Routledge.

GROOT, L. (2008), Economics, Uncertainty and European Football: Trends in Competitive Balance, Cheltenham: Edward Elgar. 
HAMIL, S.; MICHIE, J. y OUGHTON, C. (2006), A Game of two Halves. The Business of Football, http://www.bbk.ac.uk/manop/research/seanpublications/agameoftwohalves.

HEINEMANN, K. (1998), Introducción a la economía del deporte, Barcelona: Paidotribo.

HOULIHAN, B. (1997), Sport, Policy and Politics. A comparative analysis, London: Routledge.

HOWARD, D.R. y CROMPTON, J.L. (2005) Financing Sport, Morgantown: Fitness Information Technology.

HUMPHREYS, B. y HOWARD, D.R. (Eds.) (2008), The Business of Sports, Westport: Praeger Publishers.

JEANRENAUD, C. y KESENNE, S. (2006), The Economics of Sport and the Media. Cheltenham: Edward Elgar.

JONES, M.E. (Ed.) (1980), Current Issues in Professional Sports, Durham, University of New Hampshire.

KAHANE, L.H. y SHMANSKE, S. (Eds.) (2011), The Oxford Handbook of Sports Economics, Oxford: Oxford University Press.

KERN, W.S. (Ed.), (2000), The Economics of Sports, Michigan: W.E. Upjohn Institute for Employment Research.

KESENNE, S. (2007), The Economic Theory of Professional Team Sports: An Analytical Treatment, Cheltenham: Edward Elgar.

KESENNE, S. y JEANRENAUD, C. (Ed.) (1999), Competition Policy in Professional Sports. Europe after the Bosman Case, Antwerp: Standaard Editions Ltd.

LADANY, S.P. (Ed.) (1975), Management Science Applications to Leisure-Time Operations, Amsterdam: North-Holland Publishing Company.

LEIFER, E.M. (1995), Making the Majors. The transformation of Team Sports in America, Cambridge, Mass: Harvard University Press.

MACHOL, R.E.; LADANY, S.P. y MORRISON, D.G. (Eds.) (1976), Management Science in Sports, Amsterdam: North-Holland Publishing Company.

MAENNIG, W. ZIMBALIST, A. (2012), International Handbook on the Economics of Mega Sporting Events, Cheltenham: Edward Elgar.

MARBURGUER, D.R. (Eb.) (1997), Stee-Rike Four!. What's Wrong with the Business of Baseball?, Westport: Praeger.

MORROW, S. (1999), The New Business of Football. Accountability and Finance in Football, Houndmills: Palgrave Macmillan.

MORROW, S. (2003), The People's Game?. Football, Finance and Society, Houndmills: Palgrave Macmillan.

NOLL, R.G. (ed.) (1974): Government and the Sports Business, Washington D.C.: The Brookings Institution.

NOLL, R. y ZIMBALIST, A. (Eds.) (1997), Sports, Jobs \& Taxes: The Economic Impact of Sports Teams and Stadiums, Washington: Brookings Institution Press.

PREUSS, H. (2004), The Economics of Staging the Olympics. A Comparison of the Games 1972-2008, Cheltenham: Edward Elgar.

QUINN, K.G. (Ed.) (2012), The Economics of the National Football League, London: Springer.

QUIRK, J. y FORT, R. (1999), Pay Dirt: The business of Professional Team Sports, Princeton: Princeton University Press. 
QUIRK, J. y FORT, R.(1999), Hard Ball: The Abuse of Power in Pro Team Sports. Princeton: Princeton University Press.

RODRIGUEZ, P.; KESENNE, S. y GARCIA, J. (Eds) (2006), Sports Economics alter Fifty Years: Essays in Honour of Simon Rottenberg, Gijón: Ediciones de la Universidad de Oviedo.

RODRIGUEZ, P.; KESENNE, S. y GARCIA, J. (Eds.) (2007), Governance and Competition in Professional Sports Leagues, Gijón: Ediciones de la Universidad de Oviedo.

RODRIGUEZ, P.; KESENNE, S. y GARCIA, J. (Eds.) (2008), Threats to Sports and Sports Participation, Gijón: Ediciones de la Universidad de Oviedo.

RODRIGUEZ, P.; KESENNE, S. y DIETL, H. (Eds.) (2009), Social Responsability and Sustainability in Sports, Gijón: Ediciones de la Universidad de Oviedo.

RODRIGUEZ, P.; KESENNE, S. y HUMPHREYS, B. (Eds.) (2011), The Economics of Sport, Health and Happiness: the promotion of well-being through sporting activities, Cheltenham: Edward Elgar.

ROSNER, S.R y SHROPSHIRE, K.L. (2004), The Business of Sports, Sudbury, Mass.: Jones and Bartlett Publishers.

SCULLY, G.W. (1995), The Market Structure of Sports, Chicago: The University of Chicago Press.

SCULLY, G.W. (1989): The Business of Major League Baseball, Chicago: The University of Chicago Press.

SHEEHAN, R.G. (1996), Keeping Score. The Economics of Big-Time Sports, South Bend: Diamond Communications, Inc.

SHROPSHIRE, K.L. (1995), The Sports Franchise Game. Cities in Pursuit of Sports Franchises, Events, Stadiums, and Arenas, Philadelphia: University of Pennsylvania Press.

SOMMERS, P.L. (Ed.), (1992), Diamonds are forever: The Business of Baseball, Washington: The Brookings Institution.

STAUDOHAR, P.D. y MANGAN, J.A. (1991), The Business of Professional Sports, Urbana and Chicago: University of Illinois Press.

SZYMANSKY, S. (2009), Playbooks and Checkbooks: An Introduction to the Economics of Modern Sports, Princeton: Princeton University Press

SZYMANSKI, S. (2010), The Comparative Economics of Sport, New York: Palgrave Macmillan.

SZYMANSKI, S. (2010), Football Economics and Policy, London: Palgrave Macmillan.

SZYMANSKY, S. y KUYPERS, T. (1999), Winners \& Losers: The Business Strategy of Football, London: Penguin Books.

SZYMANSKY, S. y ZIMBALIST, A. (2005), National Pastime: How Americans Play Baseball And the Rest of the World Plays Soccer, Washington D.C.: Brookings Institutions Press.

TABNER, B. (1992), Through the Turnstiles, Harefield: Yore publications.

ZIMBALIST, A. (Ed.) (2001), The Economics of Sport, Cheltenham: Edward Elgar. 2 vol.

ZIMBALIST, A. (2003), May the Best Team Win: Baseball Economics and Public Policy, Washington D.C: Brookings Institution Press

ZIMBALIST, A. (2010), Circling the Bases: Essays on the Challenges and Prospects of the Sports Industry, Philadelphia: Temple University Press. 


\section{Referencias bibliográficas ARTíCULOS}

APESTEGUIA, J. y PALACIOS-HUERTA, I. (2010). "Psychological Pressure in Competitive Environments: Evidence from a Randomized Natural Experiment" en American Economic Review, 100(5), pp. 2548-64.

ASHWORTH, J. y HEYNDELS, B. (2007). "Selection bias and peer effects in team sports - The effect of age grouping on earnings of German soccer players" en Journal of Sports Economics, 8(4), pp. 355-377.

ATKINSON, S.; STANLEY, L. y TSCHIRHART, J. (1988). "Revenue Sharing as an Incentive in an Agency problem: An example from the National Football League" en Rand Journal of Economics, 19(1), pp. 27-43.

BAADE, R.A. (1996). "Professional sports as catalysts for metropolitan economic development" en Journal of Urban Affairs, 18(1), pp. 1-17.

BAADE, R.A.; BAUMANN, R. y MATHESON, V.A. (2008). "Selling the game: Estimating the economic impact of professional sports through taxable sales" en Southern Economic Journal, 74(3), pp. 794-810.

BAADE, R.A.; BAUMANN, R. y MATHESON, V.A. (2011)."Big Men on Campus: Estimating the Economic Impact of College Sports on Local Economies" en Regional Studies, 45(3), pp. 371-380.

BAADE, R.A. y MATHESON, V.A. (2001). "Home Run or Wild Pitch?: Assessing the Economic Impact of Major League Baseball's All-Star Game" en Journal of Sports Economics, 2(4), pp. 307-327.

BARGET, E. y GOUGUET, J.J. (2007). "The total economic value of sporting events Theory and practice" en Journal of Sports Economics, 8(2), pp. 165-182.

BARROS C.P.; del CORRAL, J. y GARCIA-del-BARRIO, P. (2008). "Identification of segments of soccer clubs in the Spanish League First Division with a latent class model" en Journal of Sports Economics, 9(5), pp. 451-469.

BERNARD, A. y BUSSE, M. (2003). "Who wins the Olympic Games. Economic resources and medal totals" en Review of Economics and Statistics, 86(1), pp. 413-17.

BERRI, D.J.; BROOK, S.L. y SCHMIDT, M.B. (2007). "Does one simply need to score to score?" en International Journal of Sport Finance, 2(4), pp. 190-205.

BERRI, D.J. y KRAUTMANN, A.C. (2006). "Shirking on the court: Testing for the incentive effects of guaranteed pay" en Economic Inquiry, 44(3), pp. 536-546.

BERRI, D.J.; SCHMIDT, M.B. y BROOK, S.L. (2004). "Stars at the Gate: The Impact of Star Power on NBA Gate Revenues", en Journal of Sports Economics, 5(1), pp. 3350.

BERRI, D.J. y SIMMONS, R. (2009). "Race and the Evaluation of Signal Callers in the National Football League" en Journal of Sports Economics, 10(1), pp. 23-43.

BERRI, D.J. y SIMMONS, R. (2011). "Catching a draft: on the process of selecting quarterbacks in the National Football League amateur draft" en Journal of Productivity Analysis, 35(1), pp. 37-49.

BORLAND, J. y MACDONALD, R. (2003): "Demand for Sport" en Oxford Review od Economic Policy, 19(4), pp. 478-502.

BOURG, J.F. (2008). "The extremely high income of sporting Superstars - A theoretical and empirical survey" en Revue D Economie Politique, 118 (3), pp. 375-394. 
BRANDES, L.; FRANCK, E. y NUEESCH, S. (2008). "Local heroes and superstars - An empirical analysis of star attraction in German soccer" en Journal of Sports Economics, 9(3), pp. 266-286.

BREITBARTH, T. y HARRIS, P. (2008). "The role of corporate social responsibility in the football business: Towards the development of a conceptual model" en European Sport Management Quarterly, 8(2), pp. 179-206.

BURAIMO, B. y SIMMONS, R. (2008). "Do sports fans really value uncertainty of outcome? Evidence from the English Premier League" en International Journal of Sport Finance, 3(3), pp. 146-155.

BURDEKIN, R.C.K.; HOSSFELD, R.T. y SMITH, J.K. (2005). "Are NBA Fans Becoming Indifferent to Race? Evidence From the 1990s" en Journal of Sports Economics, 6(2), pp. 144-159.

CAIRNS, J, JENNETT, N. y SLOANE, P.J. (1986): "The Economics of Professional Team Sports: A Survey of Theory and Evidence", Journal of Economic Studies, 1, pp.1-80.

CALLAN, S.J. y THOMAS, J.M. (2007). "Modeling the determinants of a professional golfer's tournament earnings - A multiequation approach" en Journal of Sports Economics, 8(4), pp. 394-411.

CAMERER, C.F. (1989). "Does the basketball market believe in the hot hand" en American Economic Review, 79(5), pp. 1257-1261.

CARMICHAEL, F. y THOMAS, D. (1993): "Bargaining in the Transfer Market: Theory and Evidence", Applied Economics, 25, Dec., pp. 1467-1476.

CARMICHAEL, F. y THOMAS, D. (2005). "Home-Field Effect and Team Performance: Evidence From English Premiership Football" en Journal of Sports Economics, 6(3), pp. 264-281.

CHALIP, L. (2006). "Toward a distinctive sport management discipline" en Journal of Sport Management, 20(1), pp. 1-21.

CHALIP, L.; GREEN, B.C. y HILL, B. (2003). "Effects of sport event media on destination image and intention to visit" en Journal of Sport Management, 17 (3), pp. 214-234.

CHELLADURAI, P. y RIEMER, H.A. (1997). "A classification of facets of athlete satisfaction" en Journal of Sport Management, 11(2), pp. 133-159.

CHIAPPORI, P.A.; LEVITT, S. y GROSECLOSE, T. (2002). "Testing mixed-strategy equilibria when players are heterogeneous: The case of penalty kicks in soccer" en American Economic Review, 92(4), pp. 1138-1151.

COATES, D. (2006). "The tax benefits of hosting the Super Bowl and the MLB All-Star game: The Houston experience" en International Journal of Sport Finance, 1(4), pp. 239-252.

COATES, D. y HUMPHREYS, B.R. (1999). "The growth effects of sport franchises, stadia, and arenas" en Journal of Policy Analysis and Management, 18(4), pp. 601-624.

COATES, D. y HUMPHREYS, B. (2002). "The Economic Impact of Postseason Play in Professional Sports" en Journal of Sports Economics, 3(3), pp. 291-299.

COATES, D. y HUMPHREYS, B.R. (2006). "Proximity benefits and voting on stadium and arena subsidies" en Journal of Urban Economics, 59(2), pp. 285-299.

COATES, D. y HUMPHREYS, B.R. (2011). "The effect of professional sports on the earnings of individuals: evidence from microeconomic data" en Applied Economics, 43(29), pp. 4449-4459. 
CROMPTON, J.L. (1995). "economic-impact analysis of sports facilities and events - 11 sources of misapplication" en Journal of Sport Management, 9(1), pp. 14-35

DAVIS, M.C. y END, C.M. (2010). "A winning proposition: The economic impact of successful national football league franchises" en Economic Inquiry, 48(1), pp. 39-50.

DAWSON, P.; DOBSON, S. y GERRARD, B. (2000). "Stochastic Frontiers and the Temporal Structure of Managerial Efficiency in English Soccer" en Journal of Sports Economics November, 1(4), pp. 341-362.

DE BOSSCHER, V., DE KNOP, P., VAN BOTTENBURG, M. Y SHIBLI, S. (2007). "A conceptual framework for analysing sports policy factors leading to international sporting success" en European Sport Management Quarterly, 6(2), pp. 185-215.

DEPKEN, C.A. (2000). "Wage disparity and team productivity: evidence from major league baseball" en Economics Letters, 67(1), pp. 87-92.

DEPKEN, C.A. y WILSON, D.P. (2004). "Wherein lies the benefit of the second referee in the NHL?" en Review of Industrial Organization, 24(1), pp. 51-72.

DIETL, H.M.; LANG, M. y RATHKE, A. (2009). "The Effect of Salary Caps in Professional Team Sports on Social Welfare" en B E Journal of Economic Analysis \& Policy, 9(1), art. $\mathrm{n}^{\circ} .17$.

DIETL, H.M.; LANG, M. y RATHKE, A. (2011). "The combined effect of salary restrictions and revenue sharing in sports leagues" en Economic Inquiry, 49(2), pp. 447-463.

DOBSON, S. y GODDARD, J. (2004). "Revenue divergence and competitive balance in a divisional sports league" en Scottish Journal of Political Economy, 51 (3), pp. 359376.

DOHERTY, A.J. y CHELLADURAI, P. (1999). "Managing cultural diversity in sport organizations: A theoretical perspective" en Journal of Sport Management, 13(4), pp. 280-297.

DOWNWARD, P.; LERA-LOPEZ, F. y RASCIUTE, S. (2011). "The Zero-inflated ordered probit approach to modelling sports participation" en Economic Modelling, 28(6), pp. 2469-2477.

DOWNWARD, P. y RASCIUTE, S. (2010). "The relative demands for Sports and leisure in England" en European Sport Management Quarterly, 10(2), pp. 189-214.

DUGGAN, M. y LEVITT, S. (2002). "Winning isn't Everything: Corruption in Sumo Wrestling" en American Economic Review, 92(5), pp. 1594-1605.

ECKARD, E.W. (2001). "Baseball's Blue Ribbon Economic Report: Solutions in Search of a Problem" en Journal of Sports Economics, 2(3): pp. 213-227.

EINOLF, K.W. (2004). "Is Winning Everything?: A Data Envelopment Analysis of Major League Baseball and the National Football League" en Journal of Sports Economics, 5(2), pp.127-151.

EL-HODIRI, M. y QUIRK, J. (1971). "An Economic Model of A Professional Sports League" en Journal of Political Economy, 79(6), pp. 1302-19.

ESPITIA-ESCUER; M.y GARCÍA-CEBRIÁN, L.I. (2004). "Measuring the Efficiency of Spanish First-Division Soccer Teams" en Journal of Sports Economics, 5(4), pp. 329-346.

EWING, B.T. (2007). "The Labor market effects of high school athletic participation - Evidence from wage and fringe benefit differentials" en Journal of Sports Economics, $8(3)$, pp. 255-265. 
FINK, J.S.; PASTORE, D.L. y RIEMER, H.A. (2001). "Do differences make a difference? Managing diversity in division IA intercollegiate athletics" en Journal of Sport Management, 15(1), pp. 10-50.

FLORES R.; FORREST D. y TENA J. D. (2010). "Impact on Competitive Balance from Allowing Foreign Players in a Sports League: Evidence from European Soccer" en Kyklos, 63(4), pp. 546-557.

FORT, R. (2006). "The value of Major League Baseball ownership" en International Journal of Sport Finance, 1(1), pp. 9-20.

FORT, R.; LEE YOUNG, H. y BERRI, D.J. (2008). "Race, Technical Efficiency, and Retention: The Case of NBA Coaches" en International Journal of Sport Finance, 3(2), pp. 84-97.

FORT, R. y QUIRK, J. (1995). "Cross-subsidization, Incentives, and Outcomes in Professional Team Sports Leagues" en Journal of Economic Literature, XXXIII (3), pp. 1265-99.

FORT, R. y MAXCY, J. (2003). "Competitive Balance in Sports Leagues: An Introduction" en Journal of Sports Economics, 4(2), pp.154-160.

FORREST, D. y SIMMONS, R. (2000). "Forecasting sport: the behaviour and performance of football tipsters" en International Journal of Forecasting, 16(3), pp. 317-331.

FORREST, D. y SIMMONS, R. (2003). "Sport and gambling" en Oxford Review of Economic Policy, 19(4), pp. 598-611.

FORREST, D. y SIMMONS, R. (2006). "New Issues in Attendance Demand: The Case of the English Football League" en Journal of Sports Economics, 7(3), pp. 247-266.

FORREST, D. y SIMMONS, R. (2008). "Sentiment in the betting market on Spanish football" en Applied Economics, 40(1), pp. 119-126.

FORREST, D.; SIMMONS, R. y SZYMANSKI, S. (2004). "Broadcasting, attendance and the inefficiency of cartels" en Review of Industrial Organization, 24 (3), pp. 243-265.

FRICK, B. (2007). "The football players' labor market: Empirical evidence from the major European leagues" en Scottish Journal of Political Economy, 54(3), pp. 422-446.

FRICK, B. (2009). "Globalization and Factor Mobility The Impact of the "Bosman-Ruling" on Player Migration in Professional Soccer" en Journal of Sports Economics, 10(1), pp. 88-106.

FRICK, B.; BARROS C.P. y PRINZ, J. (2010). "Analysing head coach dismissals in the German "Bundesliga" with a mixed logit approach" en European Journal of Operational Research, 200(1), pp. 151-159.

FRIEDMAN, M. T., PARENT, M. M. y MASON, D. S. (2008). "Building a framework for issues management in sport through stakeholder theory" en European Sport Management Quarterly, 4(3), pp. 170-190.

FRISBY, W. (2005). "The good, the bad, and the ugly: Critical sport management research" en Journal of Sport Management, 19(1), pp.1-12.

FUNK, D.C. y JAMES, J.D. (2006). "Consumer loyalty: The meaning of attachment in the development of sport team allegiance" en Journal of Sport Management, 20(2) pp. 189-217.

FUNK, D. C., TOOHEY, K. y BRUUN, T. (2008). "International sport event participation; destination image; and travel motives" en European Sport Management Quarterly, $7(3)$, pp. 227-248. 
GARCÍA, J. y RODRÍGUEZ, P. (2002). "The Determinants of Football Match Attendance Revisited: Empirical Evidence From the Spanish Football League" en Journal of Sports Economics February, 3(1), pp. 18-38.

GARCÍA, J. y RODRÍGUEZ, P. (2009). "Sports Attendance: A Survey of the Literature 1973-2007" en Rivista di Diritto ed Economia dello Sport, 5(2), pp. 111-151.

GARICANO, L.; PALACIOS-HUERTA, I. y PRENDERGAST, C. (2005). "Favoritism under social pressure" en Review of Economics and Statistics, 87(2), pp. 208-216.

GODDARD, J. y SLOANE, P. (2005). "Economics of Sport" en BOWMAKER, S.M. (Ed.), Economics Uncut, Cheltenham: Edward Elgar, pp. 345-366.

GODDARD, J. y WILSON, J.O.S. (2009). "Racial discrimination in English professional football: evidence from an empirical analysis of players' career progression" en Cambridge Journal of Economics, 33(2), pp. 295-316.

GOFF, B.L.; SHUGHART, W.F. y TOLLISON, R.D. (1998). "Moral Hazard and the Effects of the Designated Hitter Rule Revisited" en Economic Inquiry, XXXVI (84), pp. 688-92.

GREEN, M. (2006). "From 'Sport for all' to not about 'Sport' at all?: Interrogatins sport policy interventions in the United Kingdom" en European Sport Management Quarterly, 6(3), pp. 217-238.

GRIER, K.B. y TOLLISON, R.D. (1994). "The rookie draft and competitive balance - The case of professional football" en Journal of Economic Behavior \& Organization, 25(2), pp. 293-298.

HAAS, D.J. (2003). "Technical Efficiency in the Major League Soccer" en Journal of Sports Economics, 4(3), pp. 203-215.

HADLEY, L.; CIECKA, J. y KRAUTMANN, A.C. (2005). "Competitive Balance in the Aftermath of the 1994 Players' Strike" en Journal of Sports Economics, 6(4), pp. 379-389.

HALL, S. SZYMANSKI, S. y ZIMBALIST, A.S. (2002). "Testing Causality Between Team Performance and Payroll: The Cases of Major League Baseball and English Soccer" en Journal of Sports Economics, 3(2), pp. 149-168.

HILLER, H. H. (2007). "Post-event outcomes and the post-modern turn: The Olympics and urban transformations" en European Sport Management Quarterly, 6(4), pp. 317332.

HOEHN, T. y SZYMANSKI, S. (1999). "The Americanization of European Football" en Economic Policy, 28, pp. 205-33.

HOYE, R. y CUSKELLY, G. (2007). "Board power and performance within voluntary sport organisations" en European Sport Management Quarterly, 3(2), pp. 103-119.

HUMPHREYS, B.R. (2002). "Alternative Measures of Competitive Balance in Sports Leagues" en Journal of Sports Economics, 3(2), pp. 133-148.

HUMPHREYS, B.R. (2006). "The relationship between big-time college football and state appropriations for higher education" en International Journal of Sport Finance, 1(2), pp. 119-128.

HUMPHREYS, B.R. y MONDELLO, M. (2008). "Determinants of Franchise Values in North American Professional Sports Leagues: Evidence from a Hedonic Price Model" en International Journal of Sport Finance, 3(2), pp. 98-105.

HUMPHREYS, B.R. y PEREZ, L. (2012). "Network externalities in consumer spending on lottery games: evidence from Spain" en Empirical Economics, 42(3), pp. 929-945. 
HUMPHREYS, B.R. y RUSESKI, J.E. (2007). "Participation in physical activity and government spending on parks and recreation" en Contemporary Economic Policy, 25(4), pp. 538-552.

IDSON, T.L. y KAHANE, L. (2000). "Team Effects on Compensation: An Application to Salary Determination in the National Hockey League" en Economic Inquiry, 38(2), pp. 345-57.

JENNETT, N. (1984). "Attendances, uncertainty of outcome and policy in Scottish League Football" en Scottish Journal of Political Economy, 31(2), pp. 176-198.

JOHNSON, B.K.; GROOTHUIS, P.A. y WHITEHEAD, J.C. (2001). "The Value of Public Goods Generated by a Major League Sports Team: The CVM Approach" en Journal of Sports Economics February, 2(1), pp. 6-21.

JONES, J.C.H. (1969): "The Economics of the National Hockey League", Canadian Journal of Economics, 2(1), pp. 1-21

KAHN, L.M. (1993). "Free Agency, Long-Term Contracts and Compensation in Major League Baseball: Estimations from Panel Data" en Review of Economics and Statistics, LXXV (1), pp. 157-64.

KAHN, L.M. (2000). "The Sports Business as a Labor Market Laboratory" en Journal of Economic Perspectives, 14(3), pp. 75-94.

KAHN, L.M. (2006). "Race, Performance, Pay, and Retention Among National Basketball Association Head Coaches" en Journal of Sports Economics, 7(2), pp. 119-149.

KASIMATI, E. y DAWSON, P. (2009). "Assessing the impact of the 2004 Olympic Games on the Greek economy: A small macroeconometric model" en Economic Modelling, 26(1), pp. 139-146.

KELLET, P., HEDE, A. y CHALIP, L. (2008). "Social policy for sport events: Leveraging (relationships with) teams from other nations for community benefit" en European Sport Management Quarterly, 8(2), pp. 101-121.

KERSTETTER, D.L. y KOVICH, G.M. (1997). "An involvement profile of Division I women's basketball spectators" en Journal of Sport Management, 11(3), pp. 234249.

KESENNE, S. (2000). "Revenue Sharing and Competitive Balance in Professional Team Sports" en Journal of Sports Economics, 1(1), pp. 56-65.

KESENNE, S. (2000). "The impact of salary caps in professional team sports" en Scottish Journal of Political Economy, 47(4), pp. 422-430.

KESENNE, S. (2005). "Revenue Sharing and Competitive Balance: Does the Invariance Proposition Hold?" Journal of Sports Economics, 6(1), pp. 98-106.

KESENNE, S. (2007). "The peculiar international economics of professional football in Europe" en Scottish Journal of Political Economy, 54(3), pp. 388-399.

KESSENNE, S. y SZYMANSKY, S. (2004). "Competitive balance and gate revenue sharing in team sports" en Journal of Industrial Economics, LII (1), pp. 165-177.

KIKULIS, L.M. (2000). "Continuity and change in governance and decision making in national sport organizations: Institutional explanations" en Journal of Sport Management, 14(4), pp. 293-320.

KONING, R. (2003). "An Econometric Evaluation of the Effect of Firing a Coach on Team Performance" en Journal of Applied Economics, 35(5), pp. 555-64.

KRAUTMANN, A.C. (2009). "Market size and the demand for talent in major league baseball" en Applied Economics, 41(25), pp. 3267-3273. 
LEE YOUNG, H. y FORT, R. (2012). "Competitive Balance: Time Series Lessons from the English Premier League" en Scottish Journal of Political Economy, 59(3), pp. 266-282.

LENTEN, L.J.A. (2011). "The extent to which unbalanced schedules cause distortions in sports league tables" en Economic Modelling, 28(1-2), pp. 451-458.

LEOPKEY, B. y PARENT, M. M. (2009). "Risk Management issues in large-scale sporting events: A stakeholder perspective" en European Sport Management Quarterly, 9(2), pp. 187-208.

LERA-LÓPEZ, F. y RAPÚN-GÁRATE, M. (2006). "Sport participation versus consumer expenditure on sport: Different determinants and strategies in sports management" en European Sport Management Quarterly, 5(2), pp. 167-186.

LOYLAND, K. y RINGSTAD, V. (2009). "On the Price and Income Sensitivity of the Demand for Sports: Has Linder's Disease Become More Serious?" en Journal of Sports Economics, 10(6), pp. 601-618.

LUCIFORA, C. and SIMMONS, R. (2003). "Superstar Effects in Sport: Evidence From Italian Soccer" en Journal of Sports Economics, 4(1), pp.35-55.

LYNCH, J.G. y ZAX, J.S. (2000). "The Rewards to Running: Prize Structure and Performance in Professional Road Racing" en Journal of Sports Economics, 1(4), pp. 323-340.

MADDEN, J.F. (2004). "Differences in the Success of NFL Coaches by Race, 19902002: Evidence of Last Hire, First Fire" en Journal of Sports Economics, 5(1), pp. 619.

MADDEN, P. (2012). "Fan welfare maximization as a club objective in a professional sports league" en European Economic Review, 56(3), pp. 560-578.

MALONEY, M.T. y McCORMICK, R.E. (2000). "The Response of Workers to Wages in Tournaments: Evidence From Foot Races" en Journal of Sports Economics, 1 (2), pp. 99-123.

MARBURGUER, D.R. (1997). "Optimal Ticket Pricing for Performance Goods" en Managerial and Decision Economics, 18(5), pp. 375-381.

MAXCY, J.G.; FORT, R.y KRAUTMANN, A.C. (2002). "The Effectiveness of Incentive Mechanisms in Major League Baseball"" en Journal of Sports Economics, 3(3), pp. 246-255.

MORROW, S. e IDLE, C. (2008). "Understanding change in professional road cycling" en European Sport Management Quarterly, 8(4), pp. 315-335.

NADEAU, J. y O'REILLY, N. (2006). "Developing a profitability model for professional sport leagues: The case of the National Hockey League" en International Journal of Sport Finance, 1(1), pp. 46-62.

NEALE, W.C. (1964). "The Peculiar Economics of Professional Sports: A Contribution to the Theory of the Firm in Sporting Competition and in Market Competititon" en Quarterly Journal of Economics, LXXVIII(1), pp. 1-14.

NOLL, R.G. (2002). "The Economics of Promotion and Relegation in Sports Leagues: The Case of English Football" en Journal of Sports Economics, 3(2), pp. 169-203.

NOLL, R.G. (2010). "The Economics of Sports Broadcasting" en Journal of Media Economics, 23(1), pp. 42-45.

NUESCH, S. y FRANCK, E. (2009). "The Role of Patriotism in Explaining the TV Audience of National Team GamesEvidence From Four International Tournaments" en Journal of Media Economics, 22 (1), pp. 6-19. 
O'BRIEN, D. (2008). "Points of leverage: Maximizing host community benefit from a regional surfing festival" en European Sport Management Quarterly, 7(2), pp. 141165.

PARENT, M. M. y SÉGUIN, B. (2008). "Factors that led to the drowning of a world championship organizing committee: A stakeholder approach" en European Sport Management Quarterly, 7(2), pp. 187-212.

PAWLOWSKI, T., BREUER, C., WICKER, P. y POUPAUX, S. (2009). "Travel time spending behaviour in recreational sports: An econometric approach with management implications" en European Sport Management Quarterly, 9(3), pp. 215-242.

PORTER, P.K. y SCULLY, G.W. (1982). "Measuring managerial efficiency - the case of baseball" en Southern Economic Journal, 48(3), pp. 642-650.

PREUSS, H. (2006). "The economic impact of visitors at major multi-sport events" en European Sport Management Quarterly, 5(3), pp. 281-301.

QUIRK, J. y EL-HODIRI, M. (1974). "The Economic Theory of a Professional Sports League". En Noll, R. (ed.): Government and the Sports Business (pp.33-80). Washington DC: Brookings Institution.

RASCHER, D.A. y SOLMES, J.P.G. (2007). "Do fans want close contests? A test of the uncertainty of outcome hypothesis in the National Basketball Association" en International Journal of Sport Finance, 2(3), pp. 130-141.

ROTTENBERG, S. (1956). "The Baseball Players' Labor Market"en Journal of Political Economy, LXIV(3), pp. 242-58.

SANDERSON, A.R. (2002). "The Many Dimensions of Competitive Balance", en Journal of Sports Economics, 3(3), pp. 204-228.

SANDERSON, A.R. y SIEGFRIED, J. (2003). "Thinking about Competitive Balance" en Journal of Sports Economics, 4(3), pp. 255-279.

SCHMIDT, M.B. y BERRI, D.J. (2001). "Competitive Balance and Attendance: The Case of Major League Baseball" en Journal of Sports Economics, 2(2), pp. 145-167.

SCHMIDT, M.B. y BERRI, D.J. (2003). "On the evolution of competitive balance: The impact of an increasing global search" en Economic Inquiry, 41(4), pp. 692-704.

SCHMIDT, M.B. y BERRI, D.J. (2004). "The impact of labor strikes on consumer demand: An application to professional sports" en American Economic Review, 94(1), pp. 344-357.

SCULLY, G.W. (1974). "Pay and Performance in Major League Baseball" en American Economic Review, 64(6), pp. 915-30.

SIEGFRIED, J.J. (2011). "Big-Time Sports in American Universities" en Journal of Economic Literature, 49(3), pp. 754-758.

SIEGFRIED, J.J. y ZIMBALIST, A. (2000). "The Economics of Sports Facilities and their Communities" en Journal of Economic Perspectives, 14(3), pp. 95-114.

SIEGFRIED, J. y ZIMBALIST, A. (2002). "A Note on the Local Economic Impact of Sports Expenditures" en Journal of Sports Economics, 3(4), pp. 361-366.

SIMMONS, R. (2005). "Economics of Gambling", en BOWMAKER, S.M. (Ed.), Economics Uncut, Cheltenham: Edward Elgar, pp. 367-388.

SLOANE, P. (1969). "The Labour Market in Professional Football" en British Journal of Industrial Relations, 7(2), pp. 181-99.

SLOANE, P. (1971). "The Economics of Professional Football: The Football Club as a Utility Maximiser" en Scottish Journal of Political Economy, XVIII(2), pp. 121-46. 
SZYMANSKI, S. (2000). "A market test for discrimination in the English Professional Soccer Leagues"en Journal of Political Economy, 108(3), pp. 590-603.

SZYMANSKI, S. (2001). "Income inequality, competitive balance and the attractiveness of team sports: some evidence and a natural experiment from English soccer" en Economic Journal, 111(469), pp. 69-84.

SZYMANSKI, S. (2003). "The economic design of sporting contests" en Journal of Economic Literature, XLI(4), pp. 1137-1187.

SZYMANSKI, S. (2004). "Professional Team Sports are only a Game: The Walrasian Fixed-Supply Conjecture Model, Contest-Nash Equilibrium, and the Invariance Principle" en Journal of Sports Economics, 5(2), pp. 111-126.

TAKS, M. y SCHEERDER, J. (2007). "Youth sports participation styles and market segmentation profiles: Evidence and applications" en European Sport Management Quarterly, 6(2), pp. 85-121.

TAYLOR, T., DARCY, S., HOYE, R. y CUSKELLY, G. (2007). “Using psychological contract theory to explore issues in effective volunteer management" en European Sport Management Quarterly, 6(2), pp. 123-147.

TENA, J.D. y FORREST, D. (2007). "Within-season dismissal of football coaches: Statistical analysis of causes and consequences" en European Journal of Operational Research, 181(1), pp. 362-373.

Von ALLMEN, P. (2001). "Is the Reward System in NASCAR Efficient?" en Journal of Sports Economics, 2(1), pp. 62-79.

VROOMAN, J. (1995). "A General Theory of Professional Sport Leagues", Southern Economic Journal, 61(4), pp. 971-990

VROOMAN, J. (1996). "The baseball Players' Labor Market Reconsidered” en Southern Economic Journal, 63(2), pp. 339-60.

VROOMAN, J. (2009). "Theory of the Perfect Game: Competitive Balance in Monopoly Sports Leagues" en Review of Industrial Organization, 34(1), pp. 5-44.

WALKER, M. y MONDELLO, M.J. (2007). "Moving beyond economic impact: A closer look at the contingent valuation method" en International Journal of Sport Finance , 2(3), pp. 149-160.

WALTON, H.; LONGO, A. y DAWSON, P. (2008). "A contingent valuation of the 2012 London Olympic games - A regional perspective" en Journal of Sports Economics, 9(3), pp. 304-317.

WEED, M. (2006). "Sports tourism theory and method - Concepts, issues and epistemologies" en European Sport Management Quarterly, 5(3), pp. 229-242.

WICKER, P., BREUER, C. y PAWLOWSKI, T. (2009). "Promoting sport for all to agespecific target groups: The impact of sport infrastructure" en European Sport Management Quarterly, 9(2), pp. 103-118.

ZAK, T.A.; HUANG, C.J. y SIEGFRIED, J.J. (1979). "Production Efficiency: The Case of Professional Basketball", en Journal of Business, 52 (3), pp. 379-392.

ZIMBALIST, A.S. (2002). "Competitive Balance in Sports Leagues: An Introduction" en Journal of Sports Economics, 3(2), pp. 111-121.

ZIMBALIST, A.S. (2003). "Sport as Business" en Oxford Review of Economic Policy, 19(4), pp. 503-11.

ZIMBALIST, A.S. (2003). "Competitive Balance Conundrums: Response to Fort and Maxcy's Comment" en Journal of Sports Economics, 4(2), pp.161-163. 


\section{Referencias Páginas WEB}

\begin{tabular}{|c|c|}
\hline \multicolumn{2}{|l|}{ Con datos estadísticos de diversos deportes } \\
\hline www.amstat.org/sections/sis & www.nhl.com \\
\hline www.databasesports.com & www.optasports.com \\
\hline www.comunio.com & www.rmit.edu.au/sportstats \\
\hline $\begin{array}{l}\text { http://ec.europa.eu/sport/what-we-do/economic- } \\
\text { data_en.htm }\end{array}$ & $\begin{array}{l}\text { www.sportengland.org/research/official_statistics.as } \\
\text { px }\end{array}$ \\
\hline www.globalsportsmedia.com & www.sportingintelligence.com \\
\hline www.mlb.com & www.stats.com \\
\hline www.mlssoccer.com & www.transfermarkt.es \\
\hline www.nba.com & www.whoscored.com \\
\hline \multicolumn{2}{|l|}{ www.nfl.com } \\
\hline \multicolumn{2}{|l|}{ Páginas webs institucionales } \\
\hline http://www.foed.es/ & International Association of Sports Economists \\
\hline Fundación Observatorio Económico del Deporte & http://www.byuresearch.org/naasportseconomists \\
\hline http://www.cdes.fr/ & North American Association of Sports economists \\
\hline Center de Droit e d'Economie du Sport & http://www.sporteconomics.eu \\
\hline www.football-observatory.com & European Sport Economics Association \\
\hline CIES Football Observatory & http://www.sportbusinesscentre.com \\
\hline \multicolumn{2}{|l|}{ http://www.iasecon.net/ } \\
\hline \multicolumn{2}{|l|}{ Páginas web personales } \\
\hline Rodney Fort webpage & John Vrooman webpage \\
\hline https://sites.google.com/site/rodswebpages & $\begin{array}{l}\text { http://www.vanderbilt.edu/Econ/faculty/Vrooman/spo } \\
\text { rts.htm }\end{array}$ \\
\hline \multicolumn{2}{|r|}{ ( } \\
\hline International Journal of Sport Finance blog: & http://thesportseconomist.com \\
\hline http://ijsf.wordpress.com & www.footballeconomy.com \\
\hline The Sports Economist & http://eurosybalones.blogspot.com.es \\
\hline
\end{tabular}

